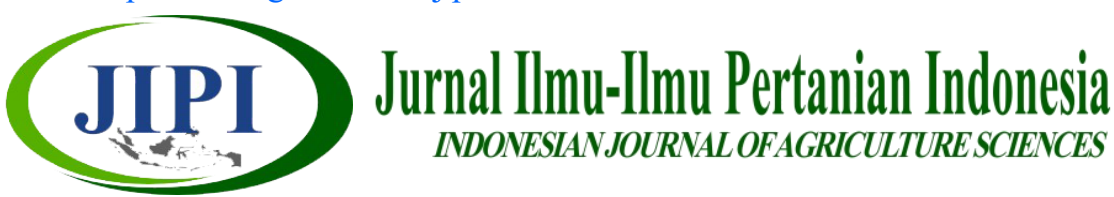

\title{
PENGARUH INSEKTISIDA NABATI KAMANDRAH DAN AKAR TUBA TERHADAP WERENG BATANG COKLAT
}

\author{
Agus Kardinan $^{1}$, Molide Rizal ${ }^{1}$, Paramita Maris ${ }^{1 *}$ \\ ${ }^{1}$ Balai Penelitian Tanaman Rempah dan Obat \\ *Corresponding Author: paramitamaris@yahoo.com
}

\begin{abstract}
[THE INFLUENCE OF BOTANICAL INSECTICIDES BASED ON CROTON OIL AND DERRIS ROOT AGAINST BROWN PLANTHOPPER]. Brown planthopper (BPH) (Nilaparvata lugens Stall) is a serious pest in rice. Using synthetic insecticide to control BPH is harmful for human health and can caused environmental pollution. The objective of this research is to find out ecofriendly insecticide to control BPH. Research has been conducted at Entomological laboratory, Indonesian Spice and Medicinal Crops Research Institute (ISMECRI), Bogor. It was designed with CRD, 16 treatments and 3 replications. Treatments consisted of botanical insecticides based on Croton tiglium and Derris elliptica. Each material was extracted by water, methanol, and xylene, and then tested by individually and combination, so there were 15 formulas and 1 control treatment (water). Third nymph BPH and IR64 rice variety were used in this research. Research was done in two methods, i.e. contact application and residual application. The result shows that there are 11 formulas which are prospective to be further developed i.e aqueous extraction ( 6 formulas) and combination extraction (aqueous with xylene and methanol ( 5 formulas). The aqueous extraction maybe the most prospective formulation since the technique could easily be adopted by farmers. Botanical pesticide based on Croton tiglium and Derris elliptica are very promising, therefore the research should be continued to find out the best formula of botanical insecticides for controlling BPH). .
\end{abstract}

Keyword: biopesticide, Croton tiglium, Derris elliptica

\begin{abstract}
ABSTRAK
Penggunaan insektisida sintetis untuk mengendalikan OPT (Organisme Pengganggu Tanaman) merupakan cara yang instan yang banyak digunakan oleh petani, namun cara ini berdampak negatif terhadap lingkungan dan juga kesehatan konsumen, oleh karena itu perlu dicari alternatif insektisida yang lebih ramah lingkungan. Penelitian ini bertujuan untuk mencari alternatif pengendalian OPT yang ramah lingkungan. Penelitian dilaksanakan di laboratorium Entomologi, Balittro yang dirancang dalam Rancangan Acak Lengkap, 16 perlakuan dan diulang 3 kali. Perlakuan terdiri dari insektisida nabati berbahan kamandrah dan akar tuba yang diekstrak dengan air, metanol dan xylene, baik diuji secara tunggal, maupun dikombinasikan, sehingga jumlah yang diuji ada 15 formula dan 1 perlakuan kontrol (air). Pengujian menngunakan nimfa wereng coklat stadium 3 dan tanaman padi jenis IR64 yang peka terhadap hama wereng coklat. Penelitian dilakukan dalam dua cara, yaitu pengujian secara kontak dan residu. Hasil penelitian menunjukkan bahwa akar tuba memberikan hasil yang baik dan konsisten saat digunakan dengan ekstraksi air, baik saat diuji secara kontak, maupun residu. Sedangkan kamandrah dengan ekstraksi air menunjukkan hasil yang kurang baik, namun dapat memberikan hasil yang baik bila diekstrak dengan metanol (ketika diuji secara residu) dan xylene (ketika diuji secara kontak). Tidak terlihat adanya sinergisme dalam campuran kedua formula akar tuba dan kamandrah terhadap mortalitas wereng coklat, baik diaplikasikan secara kontak, maupun secara residu.
\end{abstract}

Kata kunci: biopestisida, Croton tiglium, Derris elliptica 


\section{PENDAHULUAN}

Wereng Batang Coklat (WBC), Nilaparvata lugens Stal. (Homoptera: Delphacidae) adalah salah satu hama utama pada tanaman padi yang dapat menyebabkan puso (hopperburn) sehingga menimbulkan gagal panen. Pengendalian WBC oleh petani umumnya dilakukan dengan menggunakan pestisida kimia sintetik yang dikombinasikan dengan berbagai teknik pengendalian lain seperti tindakan budidaya, monitoring, varietas resisten, serta pemanfaatan musuh alami. Berdasarkan penelitian empirik di lapangan, penggunaan pestisida kimia di Indonesia telah menimbulkan kekebalan (resistensi) pada 500 jenis hama. Penggunaan pestisida sintetik untuk pengendalian hama WBC menunjukkan tren peningkatan dari tahun ke tahun, sementara terjadinya peledakan populasi hama ini di berbagai daerah juga kerap kali dilaporkan. Hal ini mengindikasikan bahwa insektisida kimia yang digunakan tidak selalu mampu mengendalikan populasi serangga tersebut. Di pihak lain penggunaan pestisida kimia secara terus menerus juga meningkatkan resiko terjadinya dampak negatif berupa terjadinya resistensi dan resurgensi hama, keracunan pada petani dan konsumen, kerusakan lingkungan, dan lainnya. Sementara penggunaan pestisida sintetik masih belum dapat ditinggalkan dalam budidaya tanaman padi, maka upaya-upaya untuk menemukan alternatif cara pengendalian yang ramah lingkungan perlu dilakukan, diantaranya dengan menggalakkan penggunaan biopestisida dan salah satunya pestisida nabati. Pemanfaatan pestisida nabati juga diharapkan dapat meminimalisasi terjadinya resistensi WBC terhadap pestisida. Oleh karena itu, perlu dilakukan penelitian guna mendapatkan formula pestisida nabati untuk mengendalikan WBC yang selain efektif juga ramah lingkungan. Dua jenis bahan pestisida nabati yang dianggap prospektif untuk mengendalikan WBC adalah akar tuba (Derris elliptica) dan Kamandrah (Croton tiglium).

Hama wereng coklat telah tersebar luas di Indonesia yang mengakibatkan kerugian yang besar, karena selain merusak langsung tanaman padi dengan mengisap cairan tanaman, juga hama ini sebagai vektor virus (Baehaki \& Mejaya, 2014). Siklus hidup wereng cokelat (telurnimfa-imago) berbeda pada setiap jenis padi, tergantung ketahanannya (Yaherwandi et al., 2009). Pengendalian yang dianjurkan adalah dengan pengendalian hama terpadu, di antaranya menggunakan varietas tahan, musuh alami seperti laba laba, kultur teknis dan lainnya (Gunawan et al., 2015), namun apabila belum efektif, dapat digunakan insektisida. Ketergantungan petani terhadap insektisida sintetis dalam mengendalikan wereng coklat sangat tinggi dan ditunjang oleh semakin banyaknya pestisida sintetis yang beredar di lapangan, sehingga mengancam kesehatan lingkungan dan manusia (Kardinan, 2014), di antaranya meningkatnya resistensi dan resurgensi hama terhadap insektisida, terkontaminasinya air tanah, menurunnya biodiversitas, dan bahaya-bahaya lain yang berkaitan dengan lingkungan (Soetopo \& Indrayani, 2007). Hasil penelitian Rasipin et al., (2014) menunjukkan bahwa penggunaan pestisida yang intensif berpengaruh terhadap peningkatan kasus pembengkakan kelenjar tiroid (gondok) pada anak-anak di sentra produksi pertanian. Oleh karena itu diperlukan suatu terobosan untuk mendapatkan insektisida yang ramah lingkungan, salah satunya adalah dengan biopestisida.

Penggunaan biopestisida harus merupakan bagian terintegrasi dari usaha pengendalian hama wereng coklat untuk meminimalisir dampak negatif terhadap kesehatan manusia, serangga yang menguntungkan seperti musuh alami, penyerbuk, organisme bukan sasaran dan lingkungan (Katty, 2013). Beberapa jenis biopestisida dilaporkan efektif mengendalikan wereng coklat, di antaranya ekstrak daun Kipait (Tithonia diversifolia) berperan sebagai penghambat daya makan (antifeedant) wereng coklat (Mokodompit et al., 2013), ekstrak daun suren dapat menekan populasi wereng coklat dan tidak berdampak negatif terhadap populasi musuh alami P. fuscipes dan L. pseudoannulata (Subandi et. al., 2016), ekstrak tembakau efektif mengendalikan populasi wereng coklat (Tuti et al., 2014), ekstrak daun kumis kucing berpengaruh terhadap mortalitas wereng coklat dengan nilai LC50 sebesar 3,5\% pada jam ke 72 setelah aplikasi (Ningsih et al., 2016). Proses produksi ekstrak tumbuhan sebagai bahan aktif pestisida sudah banyak dilakukan oleh penelitian terdahulu (Hasyim et al., 2010). Teknik formulasi yang baik merupakan cara untuk menjaga kestabilan sediaan yang berdampak langsung pada viabilitas ekstrak sebagai pestisida (Devi \& Maji, 2011), sehingga efektifitas dan persistensinya di lapangan terjaga dan pada akhirnya mampu bersaing dengan insektisida kimia sintetis.

Tanaman kamandrah (Croton tiglium L.) merupakan salah satu tanaman yang banyak terdapat di wilayah Indonesia dan telah dimanfaatkan sebagai insektisida nabati. Minyak biji kamandrah telah diteliti manfaatnya sebagai larvasida untuk nyamuk penyebab demam berdarah dengue Aedes aegypty (Ahmadi et al., 2011a; 2011b). Senyawa bahan aktif yang diprediksi bekerja sebagai insektisida adalah piperidine, 1,4-naphthoquinone, benfluralin, 2,3,6-trichlorphenol, dnoc, dan propamocarb (Ahmadi et al., 2011a). Tanaman akar tuba (Derris elliptica) ditemukan tumbuh secara liar mulai dari India sampai ke Irian Jaya, sedangkan di Afrika dan Amerika telah dibudidayakan. Di Indonesia, akar tuba terdapat hampir di seluruh wilayah nusantara. Tumbuhan ini banyak ditemukan di Jawa mulai dari dataran rendah sampai ketinggian 1500 mdpl. Akar tuba tumbuh terpencar-pencar di tempat yang tidak begitu kering, di tepi hutan, di pinggir sungai atau dalam hutan belukar yang masih liar. Bahan kimia yang terkandung dalam akar tuba adalah rotenon, deguelin, elliptone, dan toxicarol. Bagian tanaman yang digunakan adalah akar. Akar tuba berperan sebagai pestisida multifungsi yaitu sebagai 
moluskisida, insektisida, akarisida, nematisida, dan racun ikan. Rotenon merupakan insektisida berspektrum luas sebagai racun perut dan kontak yang menyebabkan kekejangan pada otot serta menyebabkan serangga berhenti makan. Kematian serangga terjadi beberapa jam sampai beberapa hari setelah terkena rotenon (Setiawati et al., 2008).

Penelitian ini bertujuan untuk mendapatkan formula insektisida nabati berbasis tanaman kamandrah (Croton tiglium) dan akar tuba (Derris elliptica) yang dapat digunakan sebagai alternatif dalam pengendalian hama wereng coklat.

\section{METODE PENELITIAN}

Penelitian dilaksanakan di Laboratorium dan Rumah kaca Hama Balai Penelitian Tanaman Rempah dan Obat Bogor, pada bulan Januari-Desember 2018.

Bahan utama yang dibutuhkan adalah bahan tanaman biji kamandrah yang diperoleh dari Balai penelitian Tanaman Industri Sukabumi dan akar tuba dari Balai Penelitian Tanaman Rempah dan Obat, Bogor. Tanaman padi yang digunakan adalah IR64 yang merupakan padi yang peka terhadap wereng coklat, dan serangga uji wereng coklat merupakan hasil perbanyakan di laboratorium; bahan kimia sebagai pelarut organik, pengemulsi dan penstabil dan bahan pembantu lainnya. Peralatan yang diperlukan adalah kurungan serangga, mini sprayer, alat-alat ukur dan takar, dan alat pembantu lainnya.
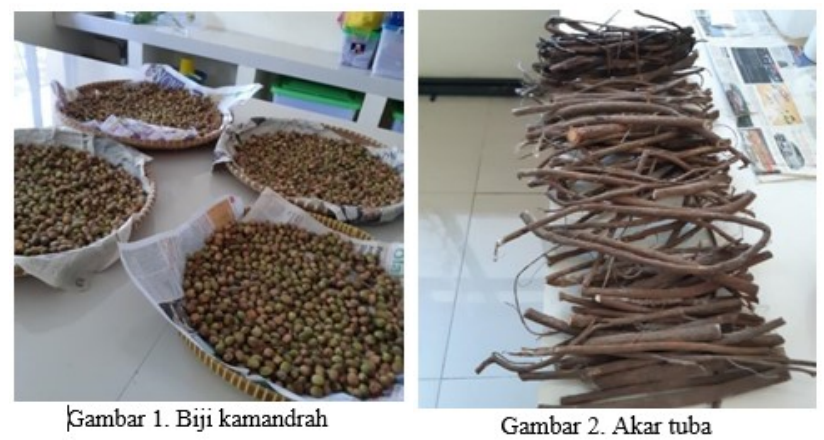

Serangga uji wereng coklat diperoleh dari tanaman padi di sekitar Bogor. Telur dan nimfa wereng coklat dipelihara dan diperbanyak pada tanaman padi yang ditanam di dalam pot volume 1 liter, yang berisi media campuran tanah dan pupuk yang telah direndam selama 2 minggu hingga menjadi lumpur. Tanaman padi yang digunakan dalam penelitian ini adalah yang telah berumur 30-35 hari setelah tanam. Pot berisi tanaman padi ini ditempatkan di dalam kurungan plastik milar yang ujungnya diberi kain kasa. Apabila makanannya habis, tanaman padi diganti dengan tanaman baru yang dimasukkan ke dalam kurungan. Nimfa wereng coklat yang digunakan dalam pengujian adalah nimfa instar-3 yang berasal dari imago turunan kedua.
Biji kamandrah dan akar tuba diekstrak dengan 3 jenis pelarut yaitu air, xylene, dan metanol, sehingga diperoleh 3 bahan insektisida nabati dari kamandrah dan 3 bahan dari akar tuba. Selain formula tunggal juga akan diuji formula campuran antara kamandrah dan akar tuba dengan perbandingan $1: 1$ (Tabel 1):

Tabel 1.Formula insektisida nabati yang diaplikasikan terhadap wereng coklat

\begin{tabular}{|c|c|c|c|}
\hline & $\begin{array}{c}\text { Kamandrah } \\
\text { (air) }\end{array}$ & $\begin{array}{c}\text { Kamandrah } \\
\text { (xylene) }\end{array}$ & $\begin{array}{c}\text { Kamandrah } \\
\text { (metanol) }\end{array}$ \\
\hline & $\mathrm{K}_{1}$ & $\mathrm{~K}_{2}$ & $\mathrm{~K}_{3}$ \\
\hline Akar tuba & $\mathrm{A}_{1} \mathrm{~K}_{1}$ & $\mathrm{~A}_{1} \mathrm{~K}_{2}$ & $\mathrm{~A}_{1} \mathrm{~K}_{3}$ \\
\hline \begin{tabular}{c} 
(air) $-\mathrm{A}_{1}$ \\
\hline $\begin{array}{c}\text { Akar tuba } \\
\text { (xylene) } \\
-\mathrm{A}_{2}\end{array}$
\end{tabular} & $\mathrm{~A}_{2} \mathrm{~K}_{1}$ & $\mathrm{~A}_{2} \mathrm{~K}_{2}$ & $\mathrm{~A}_{2} \mathrm{~K}_{3}$ \\
\hline $\begin{array}{c}\text { Akar tuba } \\
\text { (metanol) } \\
-\mathrm{A}_{3}\end{array}$ & $\mathrm{~A}_{3} \mathrm{~K}_{1}$ & $\mathrm{~A}_{3} \mathrm{~K}_{2}$ & $\mathrm{~A}_{3} \mathrm{~K}_{3}$ \\
\hline
\end{tabular}

Sehingga jumlah formula yang diuji ada 15 jenis, yaitu: 1). $\left.\left.\left.\left.\left.A_{1}, 2\right) . A_{2}, 3\right) . A_{3}, 4\right) . K_{1}, 5\right) . K_{2}, 6\right)$. $\left.\left.\left.\left.\left.K_{3}, 7\right) . A_{1} K_{1}, 8\right) . A_{2} K_{1}, 9\right) . A_{3} K_{1}, 10\right) . A_{1} K_{2}, 11\right)$. $\left.\left.\left.A_{2} K_{2}, 12\right) . A_{3} K_{2}, 13\right) . A_{1} K_{3}, 14\right) . A_{2} K_{3}$, dan 15). $\mathrm{A}_{3} \mathrm{~K}_{3}$.

Aplikasi pestisida dilakukan dengan 2 metode yaitu metode kontak langsung (semprot serangga) dan metode residu (semprot tanaman). Untuk metode kontak langsung, serangga uji diletakkan pada tanaman padi berumur sekitar satu bulan yang berada di dalam kurungan serangga, kemudian disemprotkan dengan pestisida nabati secukupnya menggunakan mini sprayer. Pengamatan kematian (mortalitas) serangga dilakukan pada 1, 3, 6, 24, 48 dan 72 Jam Setelah Aplikasi (JSA).

Untuk metode residu, tanaman padi disemprot dengan larutan pestisida menggunakan mini sprayer dengan volume yang akan dikalibrasi terlebih dahulu agar merata keseluruh tanaman, setelah itu tanaman ditutup dengan kurungan plastik milar. Setelah keringangin, dimasukkan serangga uji sebanyak 10 ekor tiap tanaman. Pengamatan kematian (mortalitas) serangga dilakukan pada 24, 48, dan 72 JSA.

Penelitian dilakukan dengan Rancangan Acak Kelompok dengan 16 perlakuan (15 formula +1 kontrol/air) dan 3 ulangan. Data dianalisis menggunakan ANOVA dua arah, apabila pengaruh perlakuan signifikan maka dilakukan uji lanjutan dengan Duncan Multiple Range Test pada taraf $5 \%$. 


\section{HASIL DAN PEMBAHASAN}

\section{Mortalitas Wereng Coklat pada Pengujian Residu Insektisida Nabati}

Hasil pengamatan menunjukkan bahwa pada pengamatan jam ke 24 setelah aplikasi, ekstrak akar tuba dengan air menunjukkan kemampuannya menekan populasi wereng coklat, diikuti ekstrak kamandrah dengan metanol dan campuran akar tuba dengan kamandrah dalam ekstraksi xylene dan air serta xylene dan metanol. Tidak terlihat adanya sinergisme antara campuran ekstrak akar tuba dengan kamandrah (Tabel 2).

Pada pengamatan jam ke 48 setelah aplikasi terlihat adanya peningkatan tingkat mortalitas pada semua perlakuan. Terlihat adanya sedikit sinergisme terutama untuk ekstrak kamandrah yang dicampur ekstrak akar tuba, namun tidak terlalu signifikan. Semua perlakuan memberikan kemampuannya dalam menekan populasi wereng coklat. Pada pengamatan jam ke 72 menunjukkan bahwa semua ekstrak insektisida nabati memperlihatkan kemampuannya dalam menekan populasi wereng coklat dengan hasil yang relatif merata (Tabel 2).

Tabel 2. Pengaruh insektisida nabati terhadap mortalitas wereng coklat yang diaplikasikan secara residu

\begin{tabular}{|l|c|c|c|}
\hline \multirow{2}{*}{ Perlakuan } & \multicolumn{3}{|c|}{ Mortalitas Wereng } \\
\cline { 2 - 4 } & 24 JSA & 48 JSA & 72 JSA \\
\hline $\mathrm{A}_{1}$ & $36,6 \mathrm{a}$ & $46,6 \mathrm{ab}$ & $60,0 \mathrm{a}$ \\
\hline $\mathrm{A}_{2}$ & 6,6 ef & $20,0 \mathrm{~d}$ & $40,0 \mathrm{c}$ \\
\hline $\mathrm{A}_{3}$ & $26,6 \mathrm{bc}$ & $40,0 \mathrm{bc}$ & $46,6 \mathrm{bc}$ \\
\hline $\mathrm{K}_{1}$ & $20,0 \mathrm{~cd}$ & $43,3 \mathrm{bc}$ & $50,0 \mathrm{ab}$ \\
\hline $\mathrm{K}_{2}$ & $16,6 \mathrm{~d}$ & $33,3 \mathrm{~cd}$ & $43,3 \mathrm{c}$ \\
\hline $\mathrm{K}_{3}$ & $30,0 \mathrm{abc}$ & $40,0 \mathrm{bc}$ & $50,0 \mathrm{ab}$ \\
\hline $\mathrm{A}_{1} \mathrm{~K}_{1}$ & $13,3 \mathrm{de}$ & $50,0 \mathrm{a}$ & $53,3 \mathrm{ab}$ \\
\hline $\mathrm{A}_{2} \mathrm{~K}_{1}$ & $33,3 \mathrm{ab}$ & $53,3 \mathrm{a}$ & $53,3 \mathrm{ab}$ \\
\hline $\mathrm{A}_{3} \mathrm{~K}_{1}$ & 10,0 e & $36,6 \mathrm{~cd}$ & $50,0 \mathrm{ab}$ \\
\hline $\mathrm{A}_{1} \mathrm{~K}_{2}$ & $26,6 \mathrm{bc}$ & $56,6 \mathrm{a}$ & $60,0 \mathrm{a}$ \\
\hline $\mathrm{A}_{2} \mathrm{~K}_{2}$ & $23,3 \mathrm{bc}$ & $53,3 \mathrm{a}$ & $63,3 \mathrm{a}$ \\
\hline $\mathrm{A}_{3} \mathrm{~K}_{2}$ & $20,0 \mathrm{~cd}$ & $36,6 \mathrm{~cd}$ & $53,3 \mathrm{ab}$ \\
\hline $\mathrm{A}_{1} \mathrm{~K}_{3}$ & $20,0 \mathrm{~cd}$ & $50,0 \mathrm{a}$ & $53,3 \mathrm{ab}$ \\
\hline $\mathrm{A}_{2} \mathrm{~K}_{3}$ & $30,0 \mathrm{ab}$ & $56,6 \mathrm{a}$ & $66,6 \mathrm{a}$ \\
\hline $\mathrm{A}_{3} \mathrm{~K}_{3}$ & $26,6 \mathrm{bc}$ & $40,0 \mathrm{bc}$ & $53,3 \mathrm{ab}$ \\
\hline $\mathrm{K}_{3}$ trol & 0,0 f & 0,0 e & $0,0 \mathrm{~d}$ \\
\hline (air) & & &
\end{tabular}

Keterangan : JSA = Jam Setelah Aplikasi Angka diikuti huruf sama pada kolom sama, berbeda tidak nyata pada DMRT $5 \%$
Tidak terlihat adanya sinergisme antara formula insektisida nabati berbasis akar tuba dan insektisida nabati berbasis kamandrah (Tabel 2). Pada ekstraksi dengan air, bahan insektisida nabati dari biji kamandrah, maupun akar tuba mampu menunjukkan potensinya dalam menekan populasi wereng coklat, sehingga teknologi ini dapat dengan mudah diterapkan dan dilaksanakan di tingkat petani. Hal ini cukup sesuai dengan penelitian yang dilakukan oleh Musa et al., (2016), yang melakukan pengujian fitokimia ekstrak akar tuba menunjukkan hasil bahwa dalam semua fraksi yang diujikan (methanol, n-hexane, ethyl acetate, dan air suling), semuanya mengandung senyawa flavonoid.

\section{Mortalitas Wereng Coklat pada Pengujian Secara Kontak}

Hasil pengamatan pada jam pertama setelah aplikasi semua formula insektisida nabati dari biji kamandrah dan akar tuba menunjukkan kemampuannya dalam menekan populasi wereng coklat (Tabel 3), namun tidak terlihat adanya sinergisme antara kedua bahan tersebut (akar tuba dan biji kamandrah).

Tabel 3. Pengaruh insektisida nabati terhadap mortalitas wereng coklat yang diaplikasikan secara kontak

\begin{tabular}{|c|c|c|c|c|c|c|}
\hline \multirow{2}{*}{$\begin{array}{l}\text { Perla } \\
\text { kuan }\end{array}$} & \multicolumn{6}{|c|}{ Mortalitas Wereng Coklat (\%) } \\
\hline & $1 \mathrm{JSA}$ & $3 \mathrm{JSA}$ & $6 \mathrm{JSA}$ & 24 JSA & 48 JSA & $72 \mathrm{JSA}$ \\
\hline$A_{1}$ & $40.0 \mathrm{a}$ & $46,6 \mathrm{ab}$ & $46,6 \mathrm{ab}$ & $46,6 \mathrm{~b}$ & $56,6 \mathrm{~b}$ & $56,6 \mathrm{~b}$ \\
\hline $\mathrm{A}_{2}$ & $23,3 \mathrm{bc}$ & $36,6 \mathrm{bc}$ & $36,6 \mathrm{bc}$ & $43,3 \mathrm{~b}$ & $46,6 \mathrm{bc}$ & $46,6 \mathrm{bc}$ \\
\hline $\mathrm{A}_{3}$ & $16,6 \mathrm{~cd}$ & $30,0 \mathrm{~cd}$ & $30,0 \mathrm{~cd}$ & $36,6 \mathrm{~cd}$ & $53,3 \mathrm{~b}$ & $56,6 \mathrm{~b}$ \\
\hline $\mathrm{K}_{1}$ & $30,0 \mathrm{ab}$ & $33,3 \mathrm{bc}$ & $33,3 \mathrm{bc}$ & $40,0 \mathrm{bc}$ & $43,3 \mathrm{bc}$ & $43,3 \mathrm{bc}$ \\
\hline $\mathrm{K}_{2}$ & 40,0 a & 50,0 a & 50,0 a & 60,0 a & 70,0 a & 70,0 a \\
\hline $\mathrm{K}_{3}$ & $30,0 \mathrm{ab}$ & $33,3 \mathrm{bc}$ & $33,3 \mathrm{bc}$ & $40,0 \mathrm{bc}$ & $46,6 \mathrm{bc}$ & $46,6 \mathrm{bc}$ \\
\hline$A_{1} K_{1}$ & $16,6 \mathrm{~cd}$ & $26,6 \mathrm{de}$ & $26,6 \mathrm{de}$ & $33,3 \mathrm{~cd}$ & $46,6 \mathrm{bc}$ & $50,0 \mathrm{~b}$ \\
\hline $\mathrm{A}_{2} \mathrm{~K}_{1}$ & $13,3 \mathrm{~cd}$ & 20,0 ef & 20,0 ef & $23,3 \mathrm{de}$ & $43,3 \mathrm{bc}$ & $43,3 \mathrm{bc}$ \\
\hline $\mathrm{A}_{3} \mathrm{~K}_{1}$ & 3,3 e & $13,3 \mathrm{f}$ & $13,3 \mathrm{f}$ & $20,0 \mathrm{e}$ & $40,0 \mathrm{bc}$ & $46,6 \mathrm{bc}$ \\
\hline$A_{1} K_{2}$ & $10,0 \mathrm{de}$ & $13,3 \mathrm{f}$ & $13,3 \mathrm{f}$ & 23,3 de & $40,0 \mathrm{bc}$ & $43,3 \mathrm{bc}$ \\
\hline $\mathrm{A}_{2} \mathrm{~K}_{2}$ & $26,6 \mathrm{bc}$ & $33,3 \mathrm{bc}$ & 33,3 bc & $36,6 \mathrm{~cd}$ & $43,3 \mathrm{bc}$ & $43,3 \mathrm{bc}$ \\
\hline $\mathrm{A}_{3} \mathrm{~K}_{2}$ & 36,6 a & 50,0 a & 50,0 a & 60,0 a & $70,0 \mathrm{a}$ & 76,6 a \\
\hline $\mathrm{A}_{1} \mathrm{~K}_{3}$ & $10,0 \mathrm{de}$ & $33,3 \mathrm{bc}$ & $33,3 \mathrm{bc}$ & $33,3 \mathrm{~cd}$ & $33,3 \mathrm{c}$ & $36,6 \mathrm{c}$ \\
\hline $\mathrm{A}_{2} \mathrm{~K}_{3}$ & $30,0 \mathrm{ab}$ & $33,3 \mathrm{bc}$ & $33,3 \mathrm{bc}$ & $36,6 \mathrm{~cd}$ & $53,3 \mathrm{~b}$ & $53,3 \mathrm{~b}$ \\
\hline $\mathrm{A}_{3} \mathrm{~K}_{3}$ & $16,6 \mathrm{~cd}$ & $26,6 \mathrm{de}$ & $26,6 \mathrm{de}$ & $36,6 \mathrm{~cd}$ & $46,6 \mathrm{bc}$ & $53,3 \mathrm{~b}$ \\
\hline $\begin{array}{l}\text { Kontr } \\
\text { ol (air) }\end{array}$ & $0,0 \mathrm{e}$ & $0,0 \mathrm{~g}$ & $0,0 \quad \mathrm{~g}$ & $0,0 \mathrm{f}$ & $0,0 \quad \mathrm{~d}$ & 0,0 \\
\hline
\end{tabular}

Keterangan : JSA = Jam Setelah Aplikasi. Angka diikuti huruf sama pada kolom sama, berbeda tidak nyata pada DMRT $5 \%$

Walaupun tidak ada hasil yang sangat menonjol dari data di atas, namun semua formula menunjukkan perbedaannya dengan kontrol yang mengindikasikan bahwa semua formula mampu menekan populasi wereng coklat, termasuk formulasi dengan menggunakan air, dimana cara ini sangat aplikatif dan dapat dilaksanakan oleh kalangan petani dengan cara yang mudah dan murah. 
Pada pengamatan jam ke 3 setelah aplikasi terjadi sedikit peningkatan tingkat mortalitas pada semua formula, namun tidak menunjukkan perbedaan yang signifikan. Hal ini terjadi hingga pengamatan jam ke 6 dan 24 setelah aplikasi, terlihat tingkat mortalitas stagnan tidak banyak berubah. Peningkatan mortalitas terjadi pada pengamatan jam ke 48 dan 72, walaupun tidak begitu besar dan hampir merata pada semua formula (Tabel 3).

Manfaat dari penelitian ini adalah memberikan informasi kepada pengguna, khususnya petani bahwa ekstraksi biji kamandrah (Croton tiglium) ataupun akar tuba (Derris elliptica) dapat dilakukan dengan air dan dampaknya diharapkan bahwa petani mempunyai alternatif pengendalian wereng coklat selain dengan insektisida kimia sintetis yang pada akhirnya dapat mengurangi ketergantungan petani terhadap insektisida kimia sintetis dan penggunaan insektisida kimia sintetis untuk mengendalikan wereng coklat dapat dikurangi.

\section{KESIMPULAN}

Diperoleh 11 formula insektisida nabati yang prospektif mengendalikan hama wereng coklat. Semua formula insektisida nabati berbasis akar tuba ataupun biji kamandrah (ekstraksi dengan air, metanol ataupun xylene) menunjukkan kemampuannya dalam menekan populasi wereng coklat, namun tidak terlihat adanya sinergisme diantara kedua bahan insektisida tersebut. Formulasi dengan air adalah teknologi formulasi yang sederhana, tetapi tidak kalah efektifitasnya dengan pelarut xylene dan metanol, sehingga cara ini sangat aplikatif di tingkat petani.

\section{DAFTAR PUSTAKA}

Ahmadi, N. R., Mangunwidjaja, D., Suparno, O. \& Pradono, D. I. (2011a). Optimasi proses ekstrasi biji kamandrah (Croton tiglium L.) dengan pengempaan dan identifikasi kandungan bahan aktifnya sebagai larvasida nabati pencegah penyakit demam berdarah dengue. J. Tek. Ind. Pert., 21(3), 154-162.

Ahmadi, N. R., Mangunwidjaja, D., Suparno, O. \& Pradono, D. I. (2011b). Pengaruh tingkat kematangan buah terhadap aktivitas larvasida dan sifat fisiko-kimia minyak kamandrah (Croton tiglium L.). Jurnal Littri, 17(4), 163-168.

Baehaki, S. E., \& Mejaya, I. M. J. (2014). Wereng cokelat sebagai hama global bernilai ekonomi tinggi dan strategi pengendaliannya. IPTEK Tanaman Pangan, 9(1), 1-12.

Devi, N., and Maji, T. K. (2011). Neem Seed Oil: Encapsulation and Controlled Release-Search for a Greener Alternative for Pest Control. In Dr. M. Stoytcheva (Ed.). Pesticides in the modern world - Pesticides Use and Management (pp. 191-232). India: InTech. Retrieved from https://www.intechopen.com/books/pesticidesin-the-modern-world-pesticides-use-andmanagement/neem-seed-oil-encapsulationand-controlled-release-search-for-a-greeneralternative-for-pest-control. 23 Juni 2020. DOI: https://10.5772/17590.

Gunawan, C. S. E., Mudjiono, G. \& Astuti, L. P. (2015). Kelimpahan populasi wereng batang cokelat Nilaparvata lugens Stal (Homoptera: Delphacidae) dan laba-laba pada budidaya tanaman padi dengan penerapan pengendalian hama terpadu dan konvensional. Jurnal HPT, $3(1), 117-122$.

Hasyim, A., Setiawati, W., Murtiningsih, R., \& Sofiari, E. (2010). Efikasi dan persistensi minyak serai sebagai biopestisida terhadap Helicoverpa armigera Hubn. (Lepidoptera: Noctuidae). J. Hort., 20(4), 377-386.

Kardinan, A. 2014. Pestisida dalam pertanian organik: prinsip-prinsip dan teknologi pertanian organik, Badan Penelitian dan Pengembangan Pertanian, IAARD Press. Jakarta.

Katti, G. (2013). Biopesticides for insect pest management in rice - present status and future scope. Journal of Rice Research, 6(1), 1-15.

Mokodompit,T.A., Konen, R., Siahaan, P. \& Tangapo, A. M. (2013). Uji ekstrak daun Tithonia diversifolia sebagai penghambat daya makan Nilaparvata lugens Stal. pada Oryza sativa. Jurnal Bios Logos, 3(2), 50-56. DOI: https:// doi.org/ 10.35799/jbl.3.2.2013.4430.

Musa, W., Ahmad, J., \& Lamangantjo, C. J. (2016). Bioactive compounds in tombili seeds and tubile roots as the alternative for synthetic pesticide to protect wheats from insects and pests. International Journal of ChemTech Research, 9(4), 604-615.

Ningsih, N. F., Ratnasari, E., \& Faizah, U. (2016). Pengaruh ekstrak daun kumis kucing (Orthosiphon aristatus) terhadap mortalitas hama wereng coklat (Nilaparvata lugens). Lentera Bio, 5(1), 14-19.

Rasipin, Suhartono, Kartini, A., \& Aeny, N. (2014). Dampak pestisida terhadap kejadian goiter (gondok) pada siswa SD di wilayah pertanian. Prinsip-prinsip dan teknologi pertanian organik. Badan Penelitian dan Pengembangan Pertanian. Jakarta.

Setiawati, W., Murtiningsih, R., Gunaeni, N., \& Rubiati, T. (2008). Pestisida nabati dari akar tuba (Derris elliptica (Wallich) Benth). In T.K. Moekasan, L. Prabaningrum, W. Hadisoeganda, A. A. Asandhi, A. S. Duriat, N. Gunadi, R. S. Basuki, E. Sofiari, dan N. Nurtika (Eds.). Tumbuhan Bahan Pestisida Nabati dan Cara Pembuatannya untuk Pengendalian Organisme Pengganggu Tumbuhan (OPT). Balai Penelitian Tanaman Sayuran. Lembang. 
Soetopo, D., \& Indrayani, I. (2007). Status teknologi dan prospek Beauveria bassiana untuk pengendalian serangga hama tanaman perkebunan yang ramah lingkungan. Perspektif, 6(1), 2946.

Subandi, M., Chaidir, L., \& Nurjanah, U. (2016). Keefektifan insektisida BPMC dan ekstrak daun suren terhadap hama wereng coklat (Nilaparvata lugens Stal.) dan populasi musuh alami pada padi varietas ciherang. Jurnal Agrikultura, 27 (3), 160-166. DOI: https://doi.org/10.24198/ agrikultura.v27i3.10879.
Tuti, H. K., Wijayanti, R., \& Supriyono. (2014). Efektifitas limbah tembakau terhadap wereng coklat dan pengaruhnya terhadap laba-laba predator. Caraka Tani - Jurnal Ilmu-ilmu Pertanian, XXIX (1), 17-24. DOI: https:// 10.20961/carakatani.v29i1.13294.

Yaherwandi, Reflinardon, \& Rahmadani, A. (2009). Biologi Nilaparvata lugens Stall (Homoptera: Delphacidae) pada empat varietas tanaman padi (Oryza sativa L.). Jurnal Biologi Edukasi, 1 (2), 9-17. 